\title{
International Engineering Congress at Glasgow
}

$\mathrm{T}$ HE selection of Glasgow for the sessions of the International Engineering Congress, organized with the co-operation of the ten leading British technical institutions, not only enabled the delegates and members to visit the numerous works and industrial establishments in and around the City, but also afforded the opportunity of holding the Congress at the Empire Exhibition at Bellahouston, with its varied and extensive display of manufactures, machinery and plant. Fully a thousand members attended the Congress, representative of the United Kingdom, the Dominions, France, Germany, Italy, Belgium, Denmark, Finland, Hungary, the United States and other countries-about twenty in all.

The opening address on June 21 was delivered by the president of the Congress, Lord Weir, who declared that it is the province of the modern engineer to restore a balance of sanity in a world containing an order of society planned for the utter destruction of civilization, characterized by the minimum of international commercial intercourse, and in which the life of every individual is limited and conditioned by the constant fear of a potential enemy. "Against this sombre picture," he said, "wherein the law of the jungle appears to be the chosen principle of evolution, it is with relief that we can descry the compensating forces of science and reason."

Mr. John Colville, Secretary of State for Scotland, and Lord Elgin, president of the Exhibition Committee, also addressed the Congress and extended to the members a cordial welcome to the metropolis of Scottish industry, the latter emphasizing his view that at a moment when all the nations of the world are thinking how to protect themselves, "it is more important to think further as to what science can do and will do in making this place better than it has been-a place where we can meet together as friends."

The papers afterwards read at the meetings on June 21-23 dealt with such varied subjects as British shipbuilding, coal, municipal and industrial planning, developments in electrical engineering, the internal combustion engine, the iron and steel industry, international air transport, naval and mechanical construction in Italy, gas, and materials research, with one of appropriate local, interest--the River Clyde and the Harbour of Glasgow.

Among some striking passages contained in these papers were the statements of Lord Sempill that the total mileage of airways which in 1919 was 3,000 , to-day has attained a figure of much more than 300,000 . Civil aircraft are now flying about 167 million miles, of which America accounts for 72 millions. The speed attained is as much as $\mathbf{4 5 0}$ miles per hour, and there is no reason why it should not be increased. An eminent French engineer, M. Mercier, president of the Union d'Electricité, stated that the total world production of electrical energy has been estimated at 310 milliard $\mathrm{kwh}$. for the year 1929 and at 450 milliard kwh. for 1937. Far from having attained its limit, consumption of electricity is developing fully with very wide possibilities before it.

On the evening of June 21, the president of the Congress gave a dinner to the official delegates, which was followed by a civic reception in the City Chambers by the Lord Provost and Corporation to all the Congress members. Through the courtesy of manufacturing firms, numerous facilities were afforded for visits to local works and factories, while excursions were also made to centres of interest farther afield. Brysson CunNingham.

\section{South-Eastern Union of Scientific Societies}

\section{Annual Congress}

\begin{abstract}
GOR its forty-third annual congress, the SouthEastern Union of Scientific Societies met at Worthing on June 21-25, a five days' congress. At the inaugural meeting, Prof. Julian Huxley, who succeeded Prof. F. E. Weiss as president, took as the subject of his presidential address "Natural History, Taxonomy and General Biology". Naturalists are now engaged, he said, in tidying up and arranging the enormous number of insects and other forms of life, and those engaged in so doing call themselves taxonomists. There are more than five thousand kinds of two-winged insects in the British Isles and nearly as many beetles. Separate species of life already catalogued number somewhere about a million. Taxonomy is becoming one of the focal points of biological research. The staffs of the museums are overburdened with their share of the work. Local naturalists can take a part, and the Association for the Study of Systematics is endeavouring to form a panel of amateur workers. Prof. Huxley advocated detailed mapping of animal-
\end{abstract}

and plant-life distribution. Evolution is going on all around us in the quiet country-side, just as much as in the deep sea, or the tropical jungle, although difficult to detect.

At the meeting of the Zoological Section, Sir Edward Poulton gave one of his fascinating lectures on "Lamarckian and Darwinian Conceptions of the Struggle for Existence", which was listened to with the attention due to one of so great authority. He was followed by Mr. J. Hornell, who read a paper on "Designing of Public Aquaria". After reviewing the mistakes made in the past in the aquaria at such places as Brighton, Southport, Blackpool and elsewhere, where amusement was mixed up with the attempts to teach science, he showed how he would design a future aquarium. Mr. Hornell was formerly director of fisheries to the Madras Govern. ment, and the erection under his guidance of the aquarium at Madras resulted in a great popular movement to study the contents of the tanks he installed. 